\title{
THE USE OF IMPORTANCE PERFORMANCE ANALYSIS TO EVALUATE THE SATISFACTION LEVEL OF THE USER OF TRANS JOGJA BUS
}

\author{
Ralina Transistari \\ Sekolah Tinggi Ilmu Manajemen YKPN Yogyakarta \\ e-mail: ralina_tr@yahoo.com
}

\begin{abstract}
The purpose of this research is to evaluate the satisfaction level of the users towards the service quality of Trans Jogja that has been operating for 8 years since the launching. This research used the Importance-Performance Analysis (IPA) method to measure the attributes that are perceived as important by the users compared to the performance all this time. The analysis was illustrated in a scatter diagram with 4 quadrants which showed the position of each attribute of the observed service quality. The attributes of service quality used referred to 5 dimensions of Service Quality, they are reliability, responsiveness, assurance, emphaty, dan tangibles with some compliances to transportation service. The data were collected by using convenience sampling method through the questionnaire contained 23 question items. From 130 questionnaires filled by the users of Trans Jogja bus route $2 \mathrm{~A}$ and $2 \mathrm{~B}$, there were only 97 respondents who are feasible for the analysis. The results showed that in Quadrant I there are 4 attributes of service quality considered important by the users, however, the reality is still out of expectations. Meanwhile, in Quadrant II and III, the attributes and performance considered important by the users have met the expectations, so that the management should maintenance the performance of the attributes. In Quadrant III, there are 6 attributes considered less-important by the users and the performance are not special, so that those are considered as less-prioritized to improve. Meanwhile, in Quadrant IV, there are only 2 attributes considered less-important by the users and perceived excessive for the performance, so that the management can allocate its resources on the other attributes. By these results, it is expected to the management of Trans Jogja bus to be able to concern on the important attributes as concerned by the users to satisfy them, so that the improvement on service quality can be more effective, both from the cost and other resources.
\end{abstract}

Keywords: Trans Jogja, importance-performance analysis, service quality, satisfaction

\begin{abstract}
Abstrak: Tujuan dari penelitian ini adalah untuk mengevaluasi tingkat kepuasan pengguna terhadap kualitas layanan Trans Jogja yang telah beroperasi selama 8 tahun sejak diluncurkan. Penelitian ini menggunakan metode Analisis Pentingnya Hasil (Performance-Performance Analysis / IPA) untuk mengukur atribut yang dianggap penting oleh pengguna dibandingkan dengan kinerja selama ini. Analisis diilustrasikan dalam diagram scatter dengan 4 kuadran yang menunjukkan posisi masing-masing atribut kualitas layanan yang diamati. Atribut kualitas layanan yang digunakan mengacu pada 5 dimensi Kualitas Pelayanan, kehandalan, daya tanggap, assurance, emphaty, dan tangibles dengan beberapa kelengkapan layanan transportasi. Data dikumpulkan dengan menggunakan metode convenience sampling melalui kuesioner yang berisi 23 item pertanyaan. Dari 130 kuesioner yang diisi oleh pengguna bus Trans Jogja 2A dan 2B, hanya ada 97 responden yang layak untuk dianalisis. Hasil penelitian menunjukkan
\end{abstract}


bahwa di Kuadran I ada 4 atribut kualitas layanan yang dianggap penting oleh pengguna, namun kenyataannya masih di luar dugaan. Sedangkan pada Quadrant II dan III, atribut dan performansi yang dianggap penting oleh pengguna telah memenuhi harapan, sehingga manajemen harus menjaga kinerja atribut. Di kuadran III, ada 6 atribut yang dianggap kurang penting oleh pengguna dan kinerjanya tidak spesial, sehingga dianggap kurang diprioritaskan untuk diperbaiki. Sedangkan pada Quadrant IV, hanya ada 2 atribut yang dianggap kurang penting oleh pengguna dan dirasakan berlebihan untuk kinerja, sehingga manajemen dapat mengalokasikan sumber dayanya pada atribut lainnya. Dengan hasil tersebut, diharapkan pengelola bus Trans Jogja dapat memperhatikan atribut penting yang bersangkutan oleh pengguna untuk memuaskan mereka, sehingga peningkatan kualitas layanan bisa lebih efektif, baik dari biaya maupun lainnya. Sumber daya

Kata kunci: Trans Jogja, analisis kinerja penting, kualitas pelayanan, kepuasan

\section{INTRODUCTION}

Trans Jogja bus has been operating for 8 years since launched by the Department of Transportation of Special Region of Yogyakarta in March 2008. The presence of Trans Jogja bus aims at addressing the needs of the citizens of Yogyakarta for a convenient alternative transportation, so that it can reduce the traffic density. It is due to the reason that the use of each bus as a facility of urban transportation is at least able to reduce the use of private vehicles for 50 units (Maryatmo, 2009).

At the beginning, Trans Jogja bus was welcomed by the citizens of Yogyakarta because the services were considered better than other public transporations, such as the availability of air conditioning, specified bus-stop, specialized-arranged routes that makes the passengers do not have to worry about getting lost, the stable bus speed than other public transportations, arranged capacity guided by the bus officers. It also uses a specialized Ticketing system, by buying only a ticket of Trans Jogja, the users can enjoy a trip to anywhere, free to move to other bus in terms not leaving the bus stop. With such advantages than other public transportations, the Trans Jogja bus is also used as a facility to promote tourism places that can be visited by the tourists, through deliberately designed routes that cross the tourism objects. The motto of the bus service is Safe, Comfortable, Reliable, Affordable, and Environmentally friendly.

Although the community supports the presence of Trans Jogja bus at the beginning, but over the time, there are some decreases in the service quality to the bus users. Inadequate maintenance leads to a worsening condition of the buses, such as the broken doors and seats which reduce the comfort and safety. The incompetent human resources also contributed to the bad services, such as less-friendly bus crews, the speeding driver, and the passengers are sometimes getting stop not on the determined bus stops due to the traffic jam. Limited number of buses also results in the longer waiting time. While the inavailability of special way for Trans Jogja bus on the highway makes the bus has to use the regular way, so that the trip time cannot always be on time and faster than other public transportations.

The decreasing service quality conditions mentioned above cannot be allowed for any longer since those can result in decrease on the number of Trans Jogja bus users and can make the people to switch back to use their own vehicles. In addition, the decreasing service quality has an impact on the image of the Yogyakarta city of 'Berhati Nyaman 
(Comfortable)' given this public transportation is also one of the tourism icons of Yogyakarta city. Therefore, this study tries to evaluate the level of satisfaction of Trans Jogja bus users and which attributes of service quality that should be the focus for improvement by the Trans Jogja bus management, based on the level of importance and performance perceived by the users.

As a facility of public transportation, in its operation, Trans Jogja bus has many parties who have a role to provide adequate services to the community. Various problems cannot be solved by one party only, but other parties, including The Provincial Government of Special Region of Yogyakarta, Department of Transportation, Trans Jogja bus management, as well as the users. Due to many problems found in the operation of the Trans Jogja bus, in order to limitation, this study is only associated with the users' responses to the Trans Jogja bus service quality in accordance with the perceived importance and performance. Meanwhile, there were 5 observed attributes, included 5 dimensions of service quality of transportation in general, not only the attributes attached to a particular stop.

This study is expected to provide suggestions/recommendations to the authorities in the operation of Trans Jogja bus on the attributes that should be the focus of concern in order to improve the service quality of public transportation to increase the user satisfaction.

\section{THEORETICAL REVIEW}

Customer Satisfaction. The measurement on customer satisfaction becomes an important issue both in service and non-service companies, given the competition in any industry is increasing. It is in line with the increasing awareness of the importance of the customer to maintain the viability of the companies, including public companies. In the measurement system of the performance of public sector companies, customer satisfaction is the result of a public service that can be categorized as a high-level goal (Mahmudi, 2005).

According to Kotler (2008), customer satisfaction is a state of feeling where someone states the results of the comparison between the performances of products (services) received and expectation. Rangkuti (2002) defines that customer satisfaction is customer response to the incompatibilities between the previously perceived importance and actual performance after use. In other words, customer satisfaction is the level of someone's feelings after comparing the performance he/she feels towards the level of importance.

Aritonang (2005) defines satisfaction as an effort to fulfill something or make something adequate. In other words, customer satisfaction is a result of customer assessment of what is expected to buy or consume a product or service. The expectation is then compared with the perception of the perceived performance. If the expectation is higher than the performance of the product, the customer will not be satisfied, and vice versa if the expectation is the same or more to a performance of the products, he/she will be satisfied.

Various definitions above clearly explain that satisfaction is formed by two measurement, namely customer expectation that is affected by the level of importance with the performance of the product. Hence, the perceived satisfaction tends to make the customers to be loyal customers, so that the companies attempt to meet customers' expectations to satisfy the customers. It makes the measurement on customer satisfaction 
is very important for the company, although the realization is not that easy. Customer satisfaction is also something that is constantly moving and not static. It makes the companies are required to improve the performance of their products or services sustainably in accordance with the customers' expectations, so that the customers are not tempted by the offer of other products or services.

Service Quality. In general, customers will be satisfied if the products or services they consume are in high-quality. The level of quality is now more subjective that is more perception-oriented, therefore, there is no objective measurement or it is not easy to measure the service quality (Arita, 2005). The level of subjectivity can use a questionnaire on customer satisfaction in order to find out customer's perception on the quality of products or services he/she consumes. This makes the attributes of quality of a product or service needs to be identified. Attributes of quality of products or services may differ according to the products or services. For example, the quality of telecommunication services companies can be measured from the attributes of price, additional services, the comfort of the procedure, call quality, and others. As for the banking companies may include the attributes of speed of service, the number of products offered, promise accuracy, professionalism, and others.

The identification of the attributes that forms the quality can be conducted through the development of dimensions of quality. The dimensions of service quality that are mostly used in many research are proposed by Parasuraman, Zeithaml, and Berry (1990), known as SERVQUAL (service quality). SERVQUAL dimensions include the dimensions of tangible, reliability, responsiveness, assurance, and empathy. Those dimensions are measured through 22 items of question derived from each dimension.

Some of the attributes of product performance that form customer satisfaction are general and some others are specific to a company (Aritonang, 2005). For example, the general attributes for service consist of assurance, service provision, complaint handling, and problem solving. While the general attributes for goods include the correlation between the goods and prices, quality, utilization, designs, consistency, and services. The specific attributes depend on the type of business, such as a computer distribution business may have the attributes of availability, timeliness, after-sales services, and technicians' skills. As for the transportation service may be related to the punctuality of departure, ticketing, baggage handling, completeness of security facilities, and so on.

Importance Performance Analysis. Martilla and James introduced Importance Performance Analysis (IPA) in 1977. IPA is presented in the form of Importance and Performance Matrix that combines the level of importance and satisfaction perceived by the customers on the services of an institution. In other words, this concept measures the level of importance according to the customer's perception in relation to what should be done by the companies that produce products or services that are of high quality.

From the various perceptions on the level of customer's importance, it can be formulated to which the most dominant variable. The concept is then associated with the importance of these variables with the reality perceived by the customer. For example, if the price becomes a very important variable for the customer (high importance), but the customer feels that the price is very expensive (low performance), it is suggested to the company to reduce the price to improve its performance. This condition can be described in Importance and Performance Matrix diagram below: 


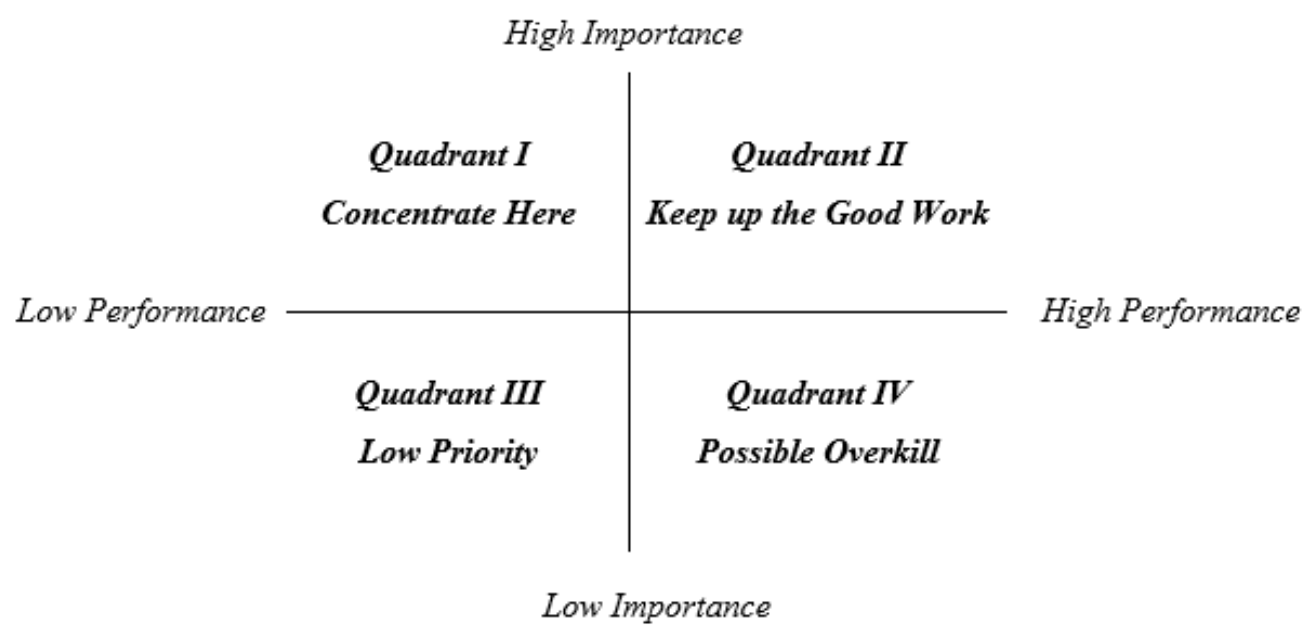

Figure 1. Importance-Performance Analysis Framework

Source: Martilla and James, 1977 follows:

The above matrix consists of 4 quadrants. Those 4 quadrants can be explained as

1. Quadrant I, high importance and low performance, Concentrate Here. This quadrant shows the area that contains the attributes considered important by users but in fact, these attributes are still out of expectations or in low level of satisfaction. The attributes included into this quadrant becomes a priority to be improved, such as by allocating adequate resources to improve performance because it is considered as an additional factor for user satisfaction.

2. Quadrant II, high importance and high performance, Keep Up the Good Work. This quadrant contains attributes considered important by the users and are as expected, so that the level of satisfaction is relatively high. Attributes that are included in this quadrant must be maintained on performance since all of these attributes make the products/services are superior in users' perceptions.

3. Quadrant III, low importance and low performance, Low Priority. This quadrant contains of the attributes of service quality considered less-important by the users and in fact, the performances are not that special. The improvement on the variables included in this quadrant may be reconsidered because of the less benefits perceived by the users, in other words, these attributes should be less-prioritized.

4. Quadrant IV, low importance and high performance, Possible Overkill.This area contains the attributes considered less important by the users and perceived as excessive. Therefore, the attributes that are included in this quadrant can be reduced to enable the companies to save costs or to allocate their resources to other attributes for higher repairment priority.

If a diagonal line is drawn from the bottom left corner to the top right, the line will show a positive correlation between performance and importance (Aritonang, 2005). If a variable is located on the diagonal line, it means that the variable can be said to have met customers' expectations. In contrast, if it is away from the diagonal line, it is not in ideal condition. It may be less satisfactory or otherwise more satisfactory for the customers. 
Previous Research. There have been many research on customer satisfaction conducted in line with the awareness of the companies on the importance of it. As a public transportation, Trans Jogja bus is interesting to be an object of research, given its services are very important to the community. Not only on the field of Management, but also of Government Science, Industrial Engineering, Public Policy, Public Administration, and others.

There were many research conducted by many researchers used the Importance and Performance Analysis (IPA) method, such as Setiawan (2005), who examined the level of user satisfaction of commuter train resulted in cleanliness and security of the station as the priority factors to be improved, Kitcharoen (2004) who conducted a research on a private university in Thailand resulted on the students who have a higher perception on the attribute of importance than the staff, but not to the attribute of performance.

The use of IPA in the research on e-government services in Japan conducted by Wong et al. (2011) and states that the IPA method is a very helpful evaluation tool to find which attributes that are performing well and which that need to upgrad and require treatment immediately. While Sezhian et al. (2011) conducted a research on a transportation company (bus) by using the IPA to distinguish between the perceptions of managers and passengers. Feng and Jeng (2005) used the IPA method on an air transportation services company with different recommendations in the strategies for improving services in accordance with the type of passengers.

A research on Trans Jogja bus was conducted by Aldila R (2011), which evaluated the performance of Trans Jogja Route 3A with the results of 1 trip time of the bus is feasible and the average departure time among the buses has no delay. Arya (2011) evaluated the new Trans Jogja bus shelters with a recommendation on better queuing system, the availability of facilities at the shelter to be completed, and the crews to inform the bus arrival schedule.

\section{RESEARCH METHOD}

Research Stages. This research began with field survey on the object of research to identify the problems occurred in Trans Jogja bus related to the service quality. The formulation of the problems were then organized and followed by the identification of variables based on various literature on related problems.

Based on the literature study and field survey, the attributes that would be asked in the questionnaire were then compiled. In order to test whether the questionnaire instruments were valid and reliable or not, there was a pretest conducted to approximately 30 respondents. The valid and reliable items were then used, while those are not valid and reliable were eliminated.

The questionnaires were then distributed to the respondents. For this purpose, the researcher engaged some college students to share their experience in conducting a research. The next stage was the tabulation of data and data analysis based on the model. Finally, based on the analysis, the conclusions and recommendations for the stakeholders were made for the improvement of the Trans Jogja bus service.

Research Location. According to the object of research, Trans Jogja bus, this research was located in Yogyakarta. The research was conducted on the bus passengers of Route $2 \mathrm{~A}$ and $2 \mathrm{~B}$ that have a route crossing Jombor Bus Station, Malioboro, Basen, Kridosono, 
UGM, Condong Catur. Especially for Route $2 \mathrm{~B}$, in addition to those routes, it also crosses Kantor Pos (Central Post Office), Wirobrajan, and Pingit.

Observed Variables. There were 5 observed dimensions of service quality referred to the research by Parasuraman et al. (1990) with some adjustments, they were: reliability, responsiveness, assurance, empathy, and tangibles. Each dimension is represented by several questions regarding services in accordance with public transport services. The questionnaire prepared by the Likert scale with five options. For the aspect of importance, the respondents were asked to give an assessment on how important the attributes of service contained in the five dimensions of service quality. Likewise, for the aspect of performance that had been perceived by the customers.

In order to ascertain whether the research instruments used were valid and reliable or not, there were validity and reliability tests conducted on the question items. The validity test was conducted by using the corrected item-total correlation, while the reliability test was seen from the Cronbach Alpha.

The Used Model. This research used the Importance-Performance Analysis (IPA) model which was initially developed by Martilla dan James in 1977. This model analyzes customer satisfaction by comparing the performance of the companies with the level of importance according to the customers on each assessed attribute.

\section{Data Collection Technique}

The population of this research includes all of the users of Trans Jogja bus Route 2A and $2 \mathrm{~B}$. The sampling was conducted by using the convenience sampling method. The data were collected through questionnaire. The questionnaire is arranged by using 5-scale Likert Scale. For the level of 'importance', the respondents were asked to provide respond on each attribute of service quality, ranging from 'very important' to 'unimportant'. Meanwhile, for the level of 'performance' the respondents were asked to provide respond ranging from 'highly satisfied' to 'dissatisfied'.

Data Analysis. Basically, the data analysis was conducted by comparing the values on each attribute (item) contained in each dimension that is between the value of performance index $(\mathrm{x})$ with the index value of importance index $(\mathrm{y})$. The results of the comparison are displayed in a matrix in the form of scatter diagram for the purpose of determining to which quadrant each item located in one dimension. The quadrant limit is determined based on the average value in each dimension.

The variables that have a value of performance below the average means should be improved, while those that are already above the average should be maintained to provide the level of customer satisfaction. Besides seeing from the performance, each variable is also seen from the value of importance, so as to give an overview to the management of which variable that needs to be improved in accordance with its importance.

\section{RESULTS AND DISCUSSION}

Validity and Reliability Tests. Before distributing the research instrument (questionnaires) to the respondents, there are validity and reliability tests firstly. The 
validity test was conducted by using Bivariate (Pearson) Correlations method to 30 respondents distributed with the results shown in Table 1 below:

Table 1. Results of Validity Tests

\begin{tabular}{ccccccc}
\hline & \multicolumn{3}{c}{ Importance } & \multicolumn{3}{c}{ Performance } \\
\cline { 2 - 7 } Attribute & $\mathrm{r}$ & Sig. & Validity & $\mathrm{r}$ & Sig. & Validity \\
\hline T1 & 0,709 & 0,000 & Valid & 0,738 & 0,000 & Valid \\
T2 & 0,760 & 0,000 & Valid & 0,514 & 0,004 & Valid \\
T3 & 0,798 & 0,000 & Valid & 0,759 & 0,000 & Valid \\
T4 & 0,895 & 0,000 & Valid & 0,632 & 0,000 & Valid \\
R1 & 0,825 & 0,000 & Valid & 0,827 & 0,000 & Valid \\
R2 & 0,765 & 0,000 & Valid & 0,664 & 0,000 & Valid \\
R3 & 0,817 & 0,000 & Valid & 0,504 & 0,005 & Valid \\
R4 & 0,783 & 0,000 & Valid & 0,738 & 0,000 & Valid \\
R5 & 0,760 & 0,000 & Valid & 0,567 & 0,001 & Valid \\
S1 & 0,865 & 0,000 & Valid & 0,747 & 0,000 & Valid \\
S2 & 0,661 & 0,000 & Valid & 0,640 & 0,000 & Valid \\
S3 & 0,607 & 0,000 & Valid & 0,604 & 0,000 & Valid \\
S4 & 0,416 & 0,022 & Valid & 0,741 & 0,000 & Valid \\
S5 & 0,634 & 0,000 & Valid & 0,678 & 0,000 & Valid \\
A1 & 0,694 & 0,000 & Valid & 0,630 & 0,000 & Valid \\
A2 & 0,731 & 0,000 & Valid & 0,609 & 0,000 & Valid \\
A3 & 0,776 & 0,000 & Valid & 0,660 & 0,000 & Valid \\
A4 & 0,751 & 0,000 & Valid & 0,710 & 0,000 & Valid \\
E1 & 0,851 & 0,000 & Valid & 0,625 & 0,000 & Valid \\
E2 & 0,671 & 0,000 & Valid & 0,611 & 0,000 & Valid \\
E3 & 0,771 & 0,000 & Valid & 0,596 & 0,001 & Valid \\
E4 & 0,418 & 0,021 & Valid & 0,759 & 0,000 & Valid \\
E5 & 0,763 & 0,000 & Valid & 0,564 & 0,001 & Valid \\
\hline
\end{tabular}

Based on the validity test by using Bivariate (Pearson) Correlations above is known that all of the statement items in questionnaire consists of 23 items are valid. While the reliability test was conducted by looking at the value of Cronbach's Alpha. The results of the test using SPSS are shown in Table 2 below:

Table 2. Results of Reliability Tests

\begin{tabular}{lcc}
\hline & \multicolumn{2}{c}{ Reliability Statistics } \\
\hline & Cronbach's Alpha & N of Items \\
\hline Importance &, 957 & 23 \\
Performance &, 939 & 23 \\
\hline
\end{tabular}

Based on the results above the value of Cronbach's Alpha for Importance is 0,957, while for the Performance is 0,939. Therefore, all of the statement items in the questionnaire are stated reliable and can be used in the research since a good reliability is $>0,60$ (Sugiyono, 2010).

Respondents. There were 130 users of Trans Jogja bus filled the questionnaires. However, there were only 97 respondents completed filling the questionnaires. The detail description of respondents can be seen in Table 3 below: 
Table 3. Respondents

\begin{tabular}{|c|c|c|c|}
\hline Description & & Total & $\%$ \\
\hline \multirow[t]{2}{*}{ Sex } & Male & 34 & 35 \\
\hline & Female & 63 & 65 \\
\hline \multirow[t]{5}{*}{ Age } & $<18$ & 23 & 24 \\
\hline & $18-25$ & 40 & 41 \\
\hline & $26-35$ & 12 & 12 \\
\hline & $36-45$ & 9 & 9 \\
\hline & $>45$ & 13 & 14 \\
\hline \multirow[t]{6}{*}{ Education } & Primary School & 6 & 6 \\
\hline & Junior High School & 17 & 18 \\
\hline & Senior High School & 48 & 49 \\
\hline & Diploma & 4 & 4 \\
\hline & Bachelor & 18 & 19 \\
\hline & Postgraduate & 4 & 4 \\
\hline \multirow[t]{6}{*}{ Job } & Student & 20 & 21 \\
\hline & College Student & 27 & 28 \\
\hline & Entrepreneur & 8 & 8 \\
\hline & Private Employee & 19 & 19 \\
\hline & Goverment Employee & 4 & 4 \\
\hline & Etc & 19 & 20 \\
\hline \multirow[t]{5}{*}{ Income } & $<0,5$ million & 41 & 42 \\
\hline & $0,5-1$ million & 18 & 19 \\
\hline & $1-2,5$ million & 16 & 17 \\
\hline & $2,5-5$ million & 12 & 12 \\
\hline & $>5$ million & 10 & 10 \\
\hline \multirow{4}{*}{$\begin{array}{l}\text { Frecuency per } \\
\text { month }\end{array}$} & $<5$ times & 41 & 42 \\
\hline & $5-10$ times & 16 & 17 \\
\hline & $11-15$ times & 7 & 7 \\
\hline &.$>15$ times & 33 & 34 \\
\hline \multirow[t]{4}{*}{ Distance } & $1-3$ kilometer & 20 & 21 \\
\hline & $4-8$ kilometer & 32 & 33 \\
\hline & $9-13$ kilometer & 25 & 26 \\
\hline & > 13 kilometer & 20 & 20 \\
\hline
\end{tabular}

From Table 3 above, most of the respondents are women, aged 18-25 years old. Meanwhile, most of the respondents are students, and college students. The most income of the respondents is under Rp500.000,00. It can be understood since most of the respondents are students or college students. Most of the respondents take the bus less than 5 times but there are also many of the respondents who take the bus more than 15 times, with most of the distance taken is 4-8 kilometers.

Data Analysis. The data analysis was conducted towards 97 respondents who filled the questionnaires completely from 130 questionnaires distributed. The average of importance and performance levels for each question item can be seen on the following table: 
Table 4. Average Value of Importance and Performance

\begin{tabular}{|c|c|c|c|c|c|}
\hline \multirow{2}{*}{ Attribute } & \multirow{2}{*}{ Quality of Service } & \multicolumn{2}{|c|}{ Importance } & \multicolumn{2}{|c|}{ Performance } \\
\hline & & Total & Average & Total & Average \\
\hline T1 & Modern buses & 568 & 5,8557 & 468 & 4,8351 \\
\hline $\mathrm{T} 2$ & $\begin{array}{l}\text { Clean and hygienic buses and shelters } \\
\text { conditions }\end{array}$ & 600 & 6,1856 & 489 & 5,0412 \\
\hline T3 & Tidy crews & 579 & 5,9691 & 520 & 5,3608 \\
\hline $\mathrm{T} 4$ & $\begin{array}{l}\text { Completed and comfortable physical } \\
\text { facilities of the buses and shelters }\end{array}$ & 583 & 6,0103 & 492 & 5,1031 \\
\hline R1 & Providing the promised services & 588 & 6,0619 & 482 & 4,9691 \\
\hline $\mathrm{R} 2$ & $\begin{array}{l}\text { Helping the users when encountering } \\
\text { any problem }\end{array}$ & 581 & 5,9897 & 482 & 4,9691 \\
\hline R3 & $\begin{array}{l}\text { Punctual arrival and departure of the } \\
\text { buses }\end{array}$ & 579 & 5,9691 & 427 & 4,4021 \\
\hline $\mathrm{R} 4$ & $\begin{array}{l}\text { The crews provide the necessary } \\
\text { information without being asked }\end{array}$ & 544 & 5,6082 & 467 & 4,8144 \\
\hline R5 & $\begin{array}{l}\text { The crews are able to explain the trip } \\
\text { routes }\end{array}$ & 587 & 6,0515 & 526 & 5,4227 \\
\hline S1 & $\begin{array}{l}\text { The crews provide the services fast and } \\
\text { professionally. }\end{array}$ & 578 & 5,9588 & 514 & 5,2990 \\
\hline $\mathrm{S} 2$ & $\begin{array}{l}\text { The crews always offer help to the } \\
\text { users }\end{array}$ & 520 & 5,3608 & 455 & 4,6907 \\
\hline S3 & $\begin{array}{l}\text { The crews have time to respond users' } \\
\text { questions }\end{array}$ & 548 & 5,6495 & 476 & 4,9072 \\
\hline S4 & $\begin{array}{l}\text { The crews provide clear information to } \\
\text { the users }\end{array}$ & 596 & 6,1443 & 502 & 5,1753 \\
\hline S5 & $\begin{array}{l}\text { The crews handle problem/damage } \\
\text { quickly }\end{array}$ & 561 & 5,7835 & 455 & 4,6907 \\
\hline A1 & $\begin{array}{l}\text { Security and comfort in using the } \\
\text { transportation services }\end{array}$ & 611 & 6,2990 & 492 & 5,0722 \\
\hline A2 & The crews provide services politely & 611 & 6,2990 & 517 & 5,3299 \\
\hline A3 & $\begin{array}{l}\text { The crews are professional and } \\
\text { trustworthy to the users }\end{array}$ & 578 & 5,9588 & 507 & 5,2268 \\
\hline A4 & $\begin{array}{l}\text { The crews are responsible on users } \\
\text { security and comfort }\end{array}$ & 595 & 6,1340 & 519 & 5,3505 \\
\hline E1 & $\begin{array}{l}\text { The crews pay attention to the children, } \\
\text { women, elderly, and disabled } \\
\text { passengers }\end{array}$ & 608 & 6,2680 & 533 & 5,4948 \\
\hline E2 & $\begin{array}{l}\text { Having the operational hours suited to } \\
\text { the users. }\end{array}$ & 581 & 5,9897 & 463 & 4,7732 \\
\hline E3 & $\begin{array}{l}\text { The crews provide fair services to the } \\
\text { users }\end{array}$ & 566 & 5,8351 & 490 & 5,0515 \\
\hline E4 & $\begin{array}{l}\text { The crews understand the individual } \\
\text { needs of the users }\end{array}$ & 505 & 5,2062 & 457 & 4,7113 \\
\hline E5 & $\begin{array}{l}\text { The crews have effective } \\
\text { communication ability }\end{array}$ & 564 & 5,8144 & 497 & 5,1237 \\
\hline & Total Average & & 5,9305 & & 5,0354 \\
\hline
\end{tabular}


The average for each question item above is illustrated into a Cartesian diagram with Performance as the horizontal axis and Importance as the vertical axis. The total average is used as the limit of each quadrant. The results can be seen on the following diagram:

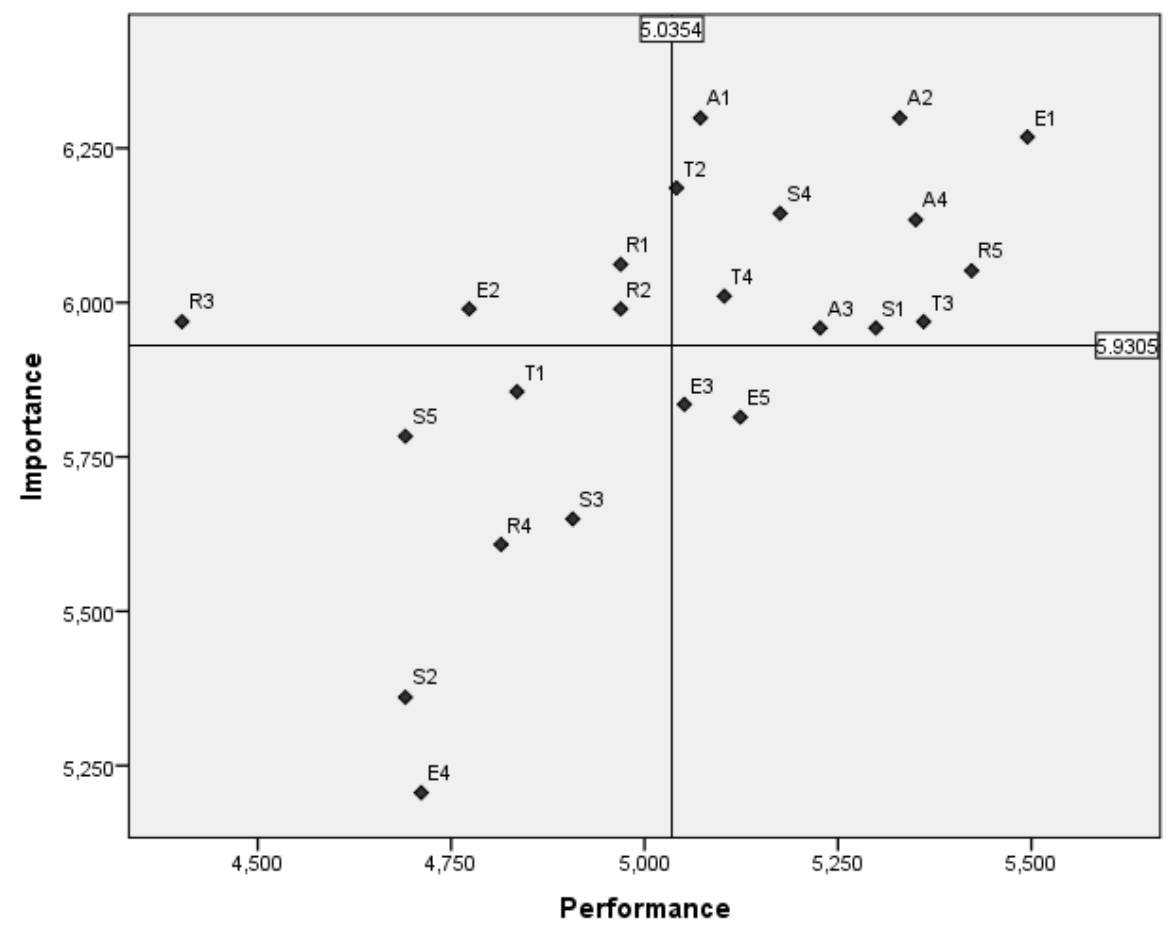

Figure 2. Importance-Performance Matrix

\section{DISCUSSION}

Based on IPA Diagram above, there are 4 quadrants, each consists of attributes of service considered to have different levels of performance and importance by the users of Trans Jogja Bus. Each quadrant will be analyzed as follows.

Quadrant I. This quadrant consists of attributes of services considered important by the users but the performances are still below the average. The attributes are: (a) Providing the promised services; (b) Helping the users when encountering any problem; (c) Punctual arrival and departure of the buses;(d) Having the operational hours suited to the users.

Those attributes have to be the focus of concern by the management of Trans Jogja bus. As a transportation facility, it is very important to consider the punctuality of departure and arrival of the buses as if it is uncertain, unreliable it will be difficult for the users to do their activities. Regarding to those attributes, the unsuitable operational hours results in the lack of interest to use the bus. The promises to users will form expectations, and expectations that are not met can result in dissatisfaction. Therefore, any promise must be fulfilled, including providing solutions when users encounter any problem.

Quadrant II. Quadrant II shows the attributes of service considered important by the users and the perceived performances are as expected. Based on the analysis above, there are 11 attributes of service of which performances are as expected by the users. The 
attributes are: (a) Clean and hygienic buses and shelters conditions; (b) Tidy crews; (c) Completed and comfortable physical facilities of the buses and shelters (d) The crews are able to explain the trip routes; (e) The crews provide the services fast and professionally; (f) The crews provide clear information to the users; (g) Security and comfort in using the transportation services; (h) The crews provide services politely; (i) The crews are professional and trustworthy to the users; (j) The crews are responsible on users security and comfort; (h) The crews pay attention to the children, women, elderly, and disabled passengers.

From 23 attributes of service observed, there are 11 attributes in this quadrant. It shows that almost $50 \%$ of the attributes are as expected by the users and satisfactory. From 11 attributes in this quadrant, there are 8 attributes that are related to the services provided by the crews. The services include appearance, explaining ability, quickness and professionalism, politeness, responsibility, attention to the special passengers (children, women, elderly, and disabled people), as well as trustworthiness. The results show that the crews are able to run their function well so that they can satisfy the users. It needs to be appreciated since it shows the adequate competence of the crews to provide the best services. They should maintain their performances. Especially for the clean and hygienic facilities of the buses and shelters, although it is included in this quadrant, the average has only a very small difference with its mean (quadrant limit), it means that this attribute should be improved continuously although it is as expected by the users.

Quadrant III. Quadrant III shows some attributes of service considered less-important by the users and the performances are not special. The attributes are: (1) Modern buses; (2) The crews provide the necessary information without being asked; (3) The crews always offer help to the users; (4) The crews have time to respond users' questions;(5) The crews handle problem/damage quickly; (6) The crews understand the individual needs of the users

In this quadrant, there are 6 attributes assessed less in performance by the users, however, since the attributes are also considered less-important, those should not be prioritized although being concerned. From 6 attributes in this quadrant, there are 5 attributes related to the crews, i.e. the crews provide information without being asked, offer help to the users, have time to respond, handle damage, understand individual needs. It shows that the users of Trans Jogja bus do not need proactive treatments. It is possible that the users have understood the bus conditions since they have used the bus routinely and do not need more information due to the simple services. For the management, those attributes are still required to improve but not to be the priority.

Quadrant IV. In this quadrant, the users perceive excessive performance for the lessimportant attributes. The analysis shows only 2 attributes as follows: (1) The crews provide fair services to the users; (2) The crews have effective communication ability.

The results show that the users have provided the services fairly and have a good communication ability. However, since the attributes are considered less-important by the users, those are perceived excessive. Thus, the services can be focused on other attributes that need to be improved. 


\section{CLOSING}

Conclusions. Based on the analysis and discussion on the previous chapter, there are some conclusions on which attributes that have met customer satisfaction and which have not as follows: (1) The attributes of service that have to be the concern for improvement are the promised services, readiness to provide help on the problems found, punctual arrival and departure, and suitable operational hours, as those have not met customer satisfaction yet; (2) The satisfactory attributes that should be maintained are the clean and completed buses and shelter conditions, tidy bus crews, and clear information including trip routes. In addition, the users also satisfy on the crew services that are fast, professional, polite, trustworthy, responsible on security, and ready to help children, women, and disabled passengers; (3) The less-important attributes that are not prioritized on services to satisfy the users are the modern condition of the buses and proactive crews such as giving information without being asked, offering help, handling the damage, and understanding individual needs. It shows that the level of services expected by the users is not that excessive; (4) There are 2 attributes that are already in good performance but are perceived as excessive by the users since those are considered less important. Those attributes are communication skills of the crews and fair crew services.

Suggestion. Based on the conclusions above, there is a suggestion for the management of Trans Jogja Bus that in order to improve the service quality for customer satisfaction, it should consider the position of each attribute of service. It is beneficial since it can make the improvement will not be in vain because the improvement is conducted based on the users' importance. In addition, it is also beneficial to save the costs and other resources.

\section{REFERENCE}

Aritonang, Lerbin R. (2005) Kepuasan Pelanggan: Pengukuran dan Penganalisisan dengan SPSS. Jakarta: PT Gramedia Pustaka Utama

Feng, Cheng-Min, Kung-Yeun Jeng. (2005) Analysis Airline Service Improvement Strategy Through Importance and Performance Analysis. Journal of the Eastern Asia Sociaty for Transformation Studies. 6 (-). 782 - 797

Kang, Bomi, Kimberly Warne, and Kay Keels. (2012) Importance-Performance Analysis of Relocation Attributes in The Carolina Coastal Region. The Coastal Business Journal. 11 (1). 84 - 100

Kitcharoen, Krisana. (2004) The Importance-Performance Analysis of Service Quality in Administrative Departments of Private Universities in Thailand. ABAC Journal. 24 (3). 20-46

Kotler, Philip. (2003) Marketing Management: Analysis, Planning, Implementation and Control, Millenium Edition. New Jersey. Prentice Hall Inc.

Mahmudi. (2005) Manajemen Kinerja Sektor Publik. Yogyakarta. Unit Penerbit dan Percetakan STIM YKPN

Martilla, J.A. and J.C. James. (1977) Importance-Performance Analysis. Journal of Marketing. 41 (1). 77-79

Maryatmo, R. (2009) Sistem Ekonomi 'Trans Jogja'. Harian Kedaulatan Rakyat. 21 Maret 
Prabawati, Aldila Riana. (2011) Evaluasi Kinerja Bus Trans Jogja Trayek 3A. Skripsi. Teknil Sipil ITS

Rangkuti, Freddy. (2003) Measuring Customer Satisfaction: Gaining Customer Relationship Strategy. Jakarta. PT Gramedia Pustaka Utama

Setiawan, Rudi. (2005) Analisa Tigkat Kepuasan Pengguna Kereta Api Komuter Surabaya - Sidoarjo. Materi Simposium FSTPT. Universitas Sriwijaya. 5-6 Desember

Sezhian M.V., Muralidharan C, Nambirajan T, and Deshmukh S.G. (2011) Developing a Performance Importance Matrix for a Public Sector Bus Transport Company: A Case Study. Theoritical and Empirical research in Urban Management. 6 (3). 5-14 Wong, Meng Seng, Nishimoto Hideki and Philip George. (2011) The Use of ImportancePerformance Analysis (IPA) in Evaluating Japan's E-goverment Services. Journal of Theoritical and Applied Electronic Commerce Research. 6 (2). 17-30

Yudhistira, Arya. (2011) Evaluasi Shelter Baru Trans Jogja terhadap Tingkat Kepentingan dan Kepuasan Pelanggan. Skripsi. Teknik Sipil UPN Veteran

Zeithaml, V.A., Parasuraman, A. and Berry L.L., (1990) Delivering Quality Service: Balancing Customer Perceptions and Expectations. New York. The Free Press http://transjogja.blogdetik.com diakses tanggal 24 Februari 2016 